\title{
ROLE OF BIOLOGICAL MESH IN SURGICAL TREATMENT OF PARACOLOSTOMY HERNIAS
}

Sergio Eduardo Alonso Araujo, Angelita Habr-Gama, Magaly Gêmio Teixeira, Pedro Paulo de Paris Caravatto, Desidério Roberto Kiss, and Joaquim GamaRodrigues

Araujo SEA, Habr-Gama A, Teixeira MG, Caravatto PP de P, Kiss DR, Gama-Rodrigues J. Role of biological mesh in surgical treatment of paracolostomy hernias. Clinics. 2005;60(4):271-6.

BACKGROUND: Paracolostomy hernia is a frequent complication of intestinal stoma. Its correction can be made through relocation of the colostomy or by keeping it in place and performing abdominal wall reinforcement through direct suturing with or without a prosthesis.

METHOD: Results of surgical treatment of paracolostomy hernias were analyzed in 22 patients who underwent surgery in our hospital during the past 15 years, with or without biological mesh (bovine pericardium). All patients had terminal colostomies after abdominoperineal excision of the rectum.

RESULTS: In $15(68.2 \%)$ patients, hernia correction was made by maintaining the colostomy in place, in 2 of them $(9.1 \%)$ without reinforcement, and in the other $13(59.1 \%)$ through reinforcement of the aponeurosis with biological mesh. In the $7(31.8 \%)$ other patients, hernia correction was accomplished by relocation of the colostomy.

The mean follow-up period was 50.2 months. Recurrence was observed in 3 (13.6\%) patients after a median of 16 months post-correction.

CONCLUSION: Paracolostomy hernia remains a surgical challenge due to its high recurrence rate. Primary repair using a prosthesis of biological material may be preferable since muscle-aponeurotic weakness is frequently observed.

KEYWORDS: Paracolostomy hernia. Colostomy construction. Surgical technique.

Surgical treatment of oncologic, inflammatory, or neurogenic diseases of the colon may eventually involve a stoma. Construction of a stoma is frequently considered a surgical procedure of secondary importance, although development of complications such as paracolostomy herniation is regarded as an almost inevitable outcome of colostomy formation. As result, complications of stomas are frequently reported, occasionally requiring early or late surgical correction. ${ }^{1-3}$

Paracolostomy hernias are quite frequent complications and can be observed in up to one third of patients who are bearers of definitive colostomies..$^{2-6}$ A paracolostomy her-

Department of Gastroenterology, Hospital das Clínicas, Faculty of Medicine, University of São Paulo - São Paulo/SP, Brazil.

E-mail: sergioed@terra.com.br

Received for publication on November 26, 2004 Accepted for publication on March 29, 2005. nia may jeopardize intestinal irrigation and adequate fixation of collecting bags, causing pain, discomfort, and damage to body image that is already altered by the presence of the colostomy; its presence represents the additional potential risk of incarceration and stenosis of the bowel. ${ }^{1,2,4,7}$

Paracolostomy hernias may occur because of technical failure during stoma construction, such as incorrect positioning or excessively wide opening of the fascia; however, they can also be associated with tissue weakness, progressive increase of intra-abdominal pressure, obesity, suture dehiscence, or defective scarring secondary to infection. .,2, $^{1,2}$

Despite its significant prevalence, there is persistent controversy in the literature regarding the best surgical option for the correction of a paracolostomy hernia. Many techniques are described all of which aim at obtaining a lower recurrence rate, and less morbidity and mortality. Among the surgical alternatives, (i) the colostomy can be 
changed from its original location (to the same or to the opposite side of the abdomen), or (ii) correction of the hernia can be accomplished with or without the placement of synthetic or biological prosthesis. ${ }^{2,5,8,9}$

The aim of this study is to report our results with surgical treatment of paracolostomy hernias in our institution through different techniques and using biological mesh when indicated, as well as to correlate recurrence findings to the operative technique.

\section{PATIENTS AND METHODS}

This study has been reviewed and approved by the Ethics Committee of our institution. All patients gave their informed consent prior their inclusion in this study.

Results of surgical treatment of paracolostomy hernias were retrospectively analyzed in 22 patients undergoing corrective surgery at the Colorectal Unit, University of São Paulo Medical School (Hospital das Clínicas) over the past 15 years.

The median age was 57.2 years; $16(72.7 \%)$ patients were women. All patients had end colostomies after abdominoperineal excision of the rectum, $18(81.8 \%)$ of them for rectal cancer and $4(18.1 \%)$ for anorectal Crohn's disease.

Full counseling in the preoperative period by an enterostomal therapist was provided to all patients.

All patients underwent complete mechanical intestinal preparation with anterograde mannitol, PEG electrolyte solution, or sodium phosphate according to the time elapsed since surgical treatment. Systemic antibiotic prophylaxis was used in all cases.

All operations were conducted under epidural or subarachnoid anesthesia, except for patients undergoing laparotomy involving relocation of the stoma who underwent general anesthesia. The procedure began with mobilization of the stoma after incision of the mucocutaneous junction, followed by resection of a cutaneous fusiform patch. The hernial sac was identified, dissected, and separated from the subcutaneous cellular tissue, and the fascial layer exposed. Opening of the hernial sac was usually required for mobilization of the appropriate extent of colonic segment to be used for a new colostomy.

In patients undergoing local correction of the hernia, the defect of the fascial layer was corrected by simple stitches of nonabsorbable synthetic thread (nylon or polypropylene) number 0 , avoiding tension. Complete closure of the skin and maturation of the colostomy was routinely employed.

In cases where a wide fascial defect was identified and a significant weakness of neighboring muscle-fascial layers was observed, biological mesh (bovine pericardium) was used. In these patients, after appropriate dissection of the hernial sac and mobilization of the bowel loop to be exposed, the muscle-fascial layer was closed without tension by direct suture using nonabsorbable stitches; the aim was to reduce the fascial defect to a size measuring between approximately 3.0 and $3.5 \mathrm{~cm}$. After that, biological mesh previously cut in a round shape to a size large enough to cover all local muscle-aponeurotic weakness, $0.5 \mathrm{~cm}$ larger than the bowel loop, was applied and fixed by simple stitches in an upper fascial position. Closing of the skin incision and maturation of the colostomy were routinely performed.

In patients with a hernia associated to an inadequate placement of the stoma, resiting of the stoma was accomplished using the following method: the abdomen was opened through the previous laparotomy incision; the stoma and hernial sac were adequately mobilized, as already described; the fascia was repaired; the new stoma was carefully constructed according to well established principles of intestinal stoma construction. These include adequate vascular supply, no tension, meticulous attention to delivering the bowel through the rectus muscle and away from scars and bony protuberances, and immediate maturation.

\section{RESULTS}

Thirteen patients $(59.1 \%)$ underwent hernia correction using biological mesh (commercially available bovine pericardium bio-prosthesis) without relocation of the colostomy. In 4 patients (18.2\%), hernia correction was accomplished by changing the colostomy site to a neighboring area on the same side of the abdomen after fascial repair without using biological mesh. In 3 patients (13.6\%), the colostomy site was changed to the other side of the abdomen after fascial repair, as already mentioned. In 2 patients (9.1\%), hernia correction was accomplished without using any prosthesis (Table 1).

There was just one case of intra-operative complication, which consisted of inadvertent lesion of the small bowel loop adhered to the hernia, which was repaired with no further complications.

Table 1 - Distribution of patients according to surgical technique

\begin{tabular}{lcc}
\hline Technique & $\mathrm{n}$ & $\%$ \\
\hline Local repair of paracolostomy hernia & 15 & 68.2 \\
- correction with biological prosthesis & 13 & 59.1 \\
- correction without biological prosthesis & 2 & 9.1 \\
Relocation of the stoma without biological & & \\
prosthesis & 7 & 31.8 \\
- same side of the abdomen & 4 & 18.2 \\
- other side of the abdomen & 3 & 13.6 \\
\hline Total & 22 & 100 \\
\hline
\end{tabular}


After a mean follow-up of 50.2 months, recurrence was observed in $3(13.6 \%)$ patients (average of 16 months after the initial correction). None of the patients had body mass index greater than $30 \mathrm{~kg} / \mathrm{m}^{2}$, and infection did not occur in the postoperative period of the first operation. One patient who initially underwent correction using biological mesh developed recurrence after 2 years. A new operation with relocation of the colostomy to the other side of the abdomen was performed. The second patient who underwent stoma relocation on the same side of the abdomen presented recurrence of the hernia after 1 year; he also underwent surgery to and relocate the colostomy to the other side of the abdomen. The third patient who initially underwent sutured hernia repair using a prosthesis had a recurrence after 13 months, but he refused an additional procedure (Table 2).

\section{DISCUSSION}

Parastomal and ventral hernias are not infrequent complications after bowel surgery. ${ }^{10-12}$ The incidence of paraileostomy hernia has been reported to range between 0.8 and 28 percent. ${ }^{13}$ Paracolostomy hernias have been reported to develop in 5 to 58 percent of patients. ${ }^{14}$ The incidence of hernia in a laparotomy incision has been reported to range between 0.5 and 15 percent in clean, uncomplicated cases. ${ }^{15-18}$ The risk of developing a hernia at any site is believed to be even higher when surgery is performed in the setting of a contaminated operative field, seroma, frank wound infection, preoperative radiation therapy, steroid therapy, and various comorbid conditions (malnutrition, diabetes, obesity, ulcerative colitis, Crohn's disease, and cancer). ${ }^{12,16}$ Technical factors ${ }^{3,4}$, such as fascial opening larger than $2.5 \mathrm{~cm}$, positioning of the stomas close to inguinal areas or lateral to the rectus muscle and not through rectus muscle, no closure of suture dehiscence of the mesenteric opening, and absence of an extraperitoneal route of the bowel loop, also act as predisposing conditions for the development of paracolostomy hernias. ${ }^{19}$

Paracolostomy hernias are associated with the impossibility of irrigating the stoma, pain, risk of entrapment or of loop strangulation, and difficulty in fixation of the collecting appliance, providing discomfort due to the deformity of body image that is already compromised by the presence of the colostomy. ${ }^{2,4,7}$

Although the main determinant factors of the etiology of paracolostomic hernias are related to surgical technique such as the correct positioning of the conduit and the creation of a fascial gap that allows only the bowel loop to be brought out, controversies persist regarding this matter. Londono-Schimmer, contrary to the opinion of several other authors, reported that that routing the bowel through the rectus muscle did not reduce the risk of development of paracolostomy hernias in 203 patients with colostomies. ${ }^{3,-}$ ${ }^{5,8,20}$ In the same series, the formation of the stoma through an extraperitoneal route reduced the occurrence of paracolostomy hernias when compared with the group in which transperitoneal routing was employed (3.6\% vs $23.6 \%$ ), supporting what Goligher and Thorlakson had previously proposed. ${ }^{1,7}$

Despite these controversies, it is probable that the early appearance of a paracolostomic hernia during the postoperative follow-up period results from the formation of an excessively large fascial gap and is, therefore, due to technical failure. Meanwhile, the formation of the hernia years after surgery is commonly related to progressive dilatation of the aponeurotic gap, associated or not with general weakness of neighboring tissues.

Because of painful symptoms, difficultly in use of collecting appliances, and body image deformity, the need for surgical repair is quite obvious. Before proceeding to any correction, the surgeon must analyze whether the stoma site is correct, whether the fascial size is adequate, and evaluate the degree of weakness of the abdominal wall. Although there are controversial points, it is logical to suppose that if the colostomy site is correct and the fascial flaw is not excessively wide, an attempt at local repair by suture (with or without biological mesh) represents an appropriate therapeutic option.

Several advantages can be obtained by maintaining the colostomy in the same site. Because the procedure is limited to the area of the stoma, without extra incisions, postoperative recovery is less painful; this is particularly important in patients with Crohn's disease who may be undergoing new surgical interventions. Reinforcement of the

Table 2 - Surgical technique for primary repair of paracolostomy hernia, recurrence rate, and surgical technique used for second repair

\begin{tabular}{lcccc}
\hline Surgical technique for first repair & $\mathrm{n}$ & Recurrence $(\mathrm{n})$ & Recurrence $(\%)$ & Surgical technique for second repair \\
\hline Biological prosthesis & 13 & 1 & 7.7 & Stoma relocation \\
Stoma relocation & 7 & 1 & 14.3 & New relocation \\
Local tissue repair & 2 & 1 & 50 & Not accomplished(patient's decision) \\
\hline \multicolumn{1}{c}{ Total } & $\mathbf{2 2}$ & $\mathbf{3}$ & $\mathbf{1 3 . 6}$ & \\
\hline
\end{tabular}


fascia may be obtained using a prosthesis with the aim of obtaining a lower recurrence rate. The use of a variety of materials (synthetic material, such as polypropylene and polytetrafluorethylene; or biological material, such as bovine pericardium) has increased over the last years. ${ }^{20-23}$ The use of mesh is believed to permit a reduction in the tension developed on fascial sutures placed for repair of hernias, especially where there is significant separation or frank loss of fascia. For this reason, mesh is believed to be particularly useful in the repair of recurrent hernias. Use of mesh has been reported to be associated with a recurrence rate of 3 to 17 percent in the repair of such "difficult" hernias. ${ }^{24-26}$ Application of the mesh is technically simple. Although there was an initial fear regarding the placement of a synthetic material in a contaminated area, many reports have shown the safety (without septic complication) associated to the use of such prosthesis. ${ }^{19,23,24}$

In fear of infectious complications, some authors advocate the placement of a prosthesis in a lower fascial plane through the peritoneum through the old midline incision ${ }^{22,27-31}$ or, more recently, laparoscopically. ${ }^{32-39}$ These approaches are claimed to be aseptic, and the operation can be performed in an otherwise potentially contaminated field. We could not agree more with the advantages of working in an aseptic field; however, if the surgeon does not dissect the hernial sac and does not correct the fascial flaw, we believe the risk of recurrence with extrusion of the prosthesis is higher. Additionally, as Stelzner et al. ${ }^{40}$ pointed out, there is a closer contact between bowel and mesh that may lead to fibrosis, erosion, and even eventual perforation, particularly when using a prosthetic mesh. Laparoscopic paracolostomy hernia repair is a minimally invasive procedure that has been adopted over the last years Although this kind of procedure is attractive because of the short operating time, reduced length of stay, less pain and less ileus, recurrence may be high since the hernial sac is not dissected nor is the defect repaired..$^{41}$ However, there are no studies analyzing a large number of patients or having a considerable follow-up period.

The potential disadvantages of a synthetic mesh are as follows: 1) it has rough edges that can erode into the bowel; 2) it may be difficult to position the mesh so that a sharp edge is not juxtaposed to bowel; 3 ) it is a semirigid material, which can cause local discomfort; and 4) a circle cut in rigid mesh has the tendency to enlarge over time, creating a high risk for recurrence. ${ }^{42}$

The authors propose the correction of the hernia using biological mesh (bovine pericardium bio-prosthesis) rather than mesh made of synthetic material. This would avoid (or perhaps more modestly "reduce the incidence of") complications such as described above. Our experience with

bioprosthetic material shows that surrounding tissues are less frequently damaged because of edges are not so sharp and pores are relatively smaller. ${ }^{29,43}$ Experimental studies have additionally shown that prosthetic mesh tends to enlarge over time ${ }^{42,44}$. Aiming to avoid this kind of complication, based on favorable past experience regarding the use of biological prosthesis and considering that a synthetic prosthesis may damage surrounding tissues more frequently due to its sharp cutting edges and relatively wide pores, ${ }^{29,43}$ as well as previous experimental studies that have shown that prosthetic mesh tends to enlarge over time, ${ }^{42,44}$ the authors propose the correction of the hernia using biological mesh (bovine pericardium bio-prosthesis) rather than with mesh made of synthetic material.

Although often clinically evident, hernia recurrence at any site may be subtle. Confirmation of recurrence by CT or ultrasound may be required, particularly in the obese patient. Clinical recurrence determination alone is likely to underestimate true recurrence rates. Recurrence after sim-

PARACOLOSTOMY HERNIA

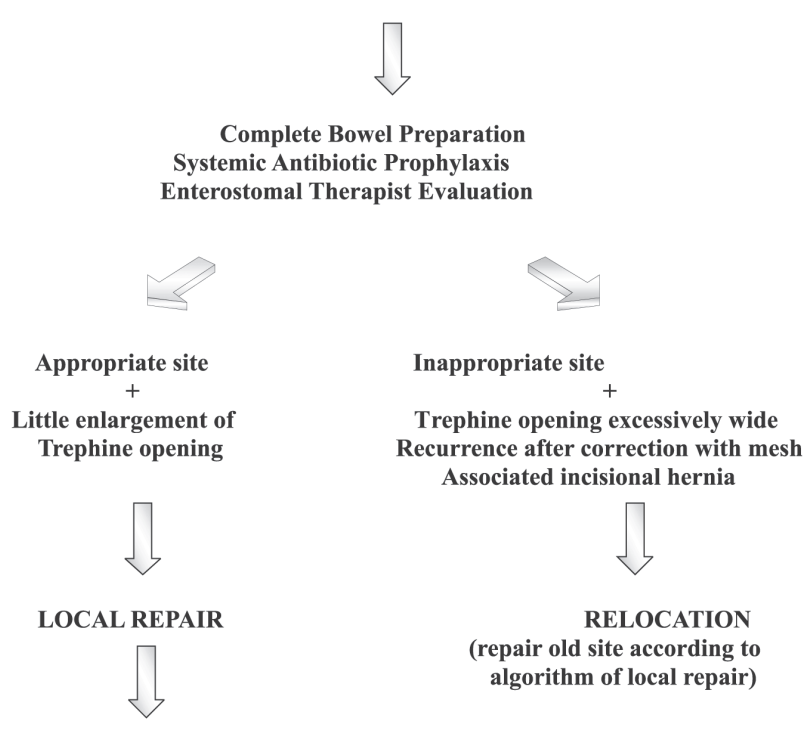

Muscle/aponeurotic weakness?

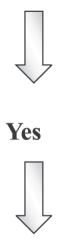

Repair with biological mesh

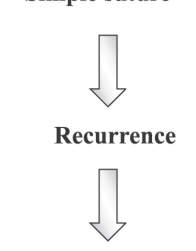

Repair with biological mesh

Figure 1 - Surgical management of paracolostomy hernias 
ple repair of a ventral hernia has been reported to be 10 to 55 percent. ${ }^{46}$ When local repair is considered with this technique, a recurrence rate of $7.7 \%$ was obtained in our series. In situations of incorrect positioning of the stoma associated or not with accentuated fascial and muscle weaknesses, as already mentioned, the stoma site must be changed. ${ }^{8}$ In our series, this technical procedure led to 1 (4.5\%) recurrence case. Therefore, attempting stoma relocation without laparotomy, although attractive, may be related to a higher risk of a new hernia. This conclusion, however, may not be obtained by the analysis of our data due to a reduced number of cases. In our sample population, we did not observe any case of rejection or infection.

When changing the colostomy site, there is a risk of a hernia developing in the old colostomy site, which may be avoided by using mesh for fascial reinforcement.9,21,22 Repair with mesh should not allow new hernias when it is technically well performed, since the mesh adds strength to the abdominal wall. In our series, reinforce- ment of the old colostomy site was performed by simple suture.

It was also possible to verify that although hernias are a common complication of permanent stomas, they have been observed in only a few cases ( 22 cases after 15 years) in our experience. The authors attribute this result to the strict application of technical principles established for the construction of intestinal stomas. ${ }^{45}$

\section{CONCLUSION}

Evaluation of fascial opening, stoma location, and associated tissue weakness, although subjective, remain sound surgical principles for adequately repairing paracolostomy hernias, although there may be not only one correct approach for each case. Based on the results of this study, the authors submit for discussion an algorithm for the surgical management of paracolostomy hernias when reconstruction of intestinal tract is not foreseen or cannot be accomplished (Figure 1).

\section{RESUMO}

Araujo SEA, Habr-Gama A, Teixeira MG, Caravatto PP de P, Kiss DR, Gama-Rodrigues J. Uso de prótese biológica no tratamento cirúrgico de hérnias paracolostômicas. Clinics. 2005;60(4):271-6.

Hérnias paracolostômicas são complicações freqüentes de estomas intestinais. A correção pode ser realizada através do seu reposicionamento ou mantendo a mesma localização, associada ao reforço da parede abdominal com ou sem o emprego de prótese.

MÉTODOS: Os resultados do tratamento cirúrgico de hérnias paracolostômicas são analisados em 22 pacientes em nosso serviço nos últimos 15 anos. Todos os pacientes eram portadores de colostomias terminais após ressecção abdominoperineal do reto.
RESULTADOS: Em 15 (68,2\%) pacientes, a correção da hérnia foi realizada mantendo-se a colostomia no local original, em $2(9,1 \%)$ deles através de herniorrafia simples e em $13(59,1 \%)$ com reforço da aponeurose com prótese biológica. Nos outros 7 (31,8\%) pacientes, a correção foi realizada por reposicionamento da colostomia. O seguimento médio pós-operatório foi de 50,2 meses. Recidiva foi observada em 3 (13,6\%) casos (em média 16 meses após correção).

CONCLUSÃO: A hérnia paracolostômica continua a ser um desafio cirúrgico devido a sua elevada recidiva. Correção primária com prótese pode ser favorecida, uma vez que frequientemente se observa fraqueza da aponeurose.

UNITERMOS: Hérnia paracolostômica. Confecção de colostomia. Técnica cirúrgica.

\section{REFERENCES}

1. Abdu RA. Repair of paracolostomy hernias with Marlex mesh. Dis Colon Rectum. 1982;25(6):529-31.

2. Allen-Mersh TG, Thomsom JP. Surgical treatment of colostomy complications. Br J Surg. 1988;75(5):416-8.

3. Barnett JE, Endrey-Walder P, Pheils MT. Closure of colostomy. Aust N Z J Surg. 1976;46(2):131-3.

4. Cheung MT. Complications of an abdominal stoma: an analysis of 322 stomas. Aust N Z J Surg. 1995;65(11):808-11.
5. Goligher J. Surgery of the anus, rectum and colon. $5^{\text {th }}$ ed. London: Bailliers Tindall; 1984.

6. Habr-Gama A, Raia A, Corrêa Neto A. Colostomias - considerações gerais. Rev Paul Med. 1961;45(5):221-32.

7. Habr-Gama A, Pigossi N, Gama-Rodrigues JJ. Emprego de duramáter homóloga na reconstrução do assoalho pélvico. Rev Bras Cir. 1978;5(5):203-12. 
8. Habr-Gama A, Teixeira MG, Vasconcelos Jr HR. Hérnias paracolostômicas. Rev Bras Colo-Proct. 1993;13(3):133-5.

9. Hines JR, Harris GD. Colostomy and colostomy closure. Surg Clin North Am. 1977;57(6):1379-82.

10. Teixeira MG, Ponte ACA, Sousa M, Almeida MG, Silva Filho E, Calache JE, Habr-Gama A, Kiss DR. Short- and long-term outcomes of ileal pouch-anal anastomosis for ulcerative colitis. Rev Hosp Clin Fac Med S Paulo. 2003;58:193-198.

11. Habr-Gama A, Sobrado CW, Araujo SEA, Nahas SC, Birbojm I, Nahas CSR et al. Surgical treatment of anal stenosis: assessment of 77 anoplasties. Clinics. 2005;60:17-20.

12. Devlin H. Peristomal hernia. In: Nyhus LM, Condon RE, eds. Hernia. Philadelphia: JB Lippincott, 1989.

13. Rubin MS, Schoetz DJ, Matthews JB. Parastomal hernia: is stoma relocation superior to fascial repair? Arch Surg. 1994;129:413-9.

14. Gilbert A, Graham M, Voigt W. Incisional, epigastric and umbilical hernias. In: Cameron JL, ed. Current surgical therapy. 7th ed. St. Louis: CV Mosby, 2001.

15. Williams JG, Etherington R, Hayward MW, Hughes LE. Paraileostomy hernia: a clinical and radiological study. Br J Surg. 1990;77:1355.

16. Usher F. Hernia repair with knitted polypropylene mesh. Surg Gynecol Obstet. 1963;117:239-40.

17. Korenkov M, Sauerland S, Arndt M, Bograd L, Neugebauer EA, Troidl H. Randomized clinical trial of suture repair, polypropylene mesh or autodermal hernioplasty for incisional hernia. Br J Surg. 2002;89:50-6.

18. Condon R. Incisional hernia. In: Nyhus LM, Condon RE, eds. Hernia. Philadelphia: JB Lippincott, 1995.

19. Wissing J, Van Vroonhoven TJ, Schattenkerk ME, Veen HF, Ponsen RJ, Jeekel J. Fascia closure after midline laparotomy: results of a randomized trial. Br J Surg. 1987;74:738-41.

20. Mudge M, Hughes LE. Incisional hernia: a 10-year prospective study of incidence and attitudes. Br J Surg. 1985;72:70-1.

21. Rosin JD, Bonardi RA. Paracolostomy hernia repair with Marlex mesh: a new technique. Dis Colon Rectum. 1977;20(4):299-302.

22. Saha SP, Rao N, Stephenson SE. Complications of colostomy. Dis Colon Rectum. 1973;16(6):515-6.

23. Sitzmann JV. A new alternative to diverting double-barreled ileostomy. Surg Gynecol Obstet. 1987;165(5):461-4.

24. Sugarbaker PH. Prosthetic mesh repair of large hernias at the site of colonic stomas. Surg Gynecol Obstet. 1980;150(4):577-9.

25. Sugarbaker PH. Peritoneal approach to prosthetic mesh repair of paraostomy hernias. Ann Surg. 1985;201(3):344-6.

26. Birolini C, Utiyama EM, Rodrigues AJ, Birolini D. Elective colonic operation and prosthetic repair of incisional hernia: does contamination contraindicate abdominal wall prosthesis use? J Am Coll Surg. 2000;191:366-72.

27. Kennedy GM, Matyas JA. Use of expanded polytetrafluoroethylene in the repair of the difficult hernia. Am J Surg. 1994;168:304-6.

28. McLanahan D, King LT, Weems C, Novotney M, Gibson K. Retrorectus prosthetic mesh repair of midline abdominal hernia. Am J Surg. 1997;173:445-9.
29. Hofstetter WL, Vukasin P, Ortega AE, Anthone G, Beart RW Jr New technique for Mesh repair of paracolostomy hernias. Dis Colon Rectum. 1988;41(8):1054-5.

30. Byers JM, Steinberg JB, Postier RG. Repair of parastomal hernias using polypropylene mesh. Arch Surg. 1992;127(10):1246-7.

31. Morris-Stiff G, Hughes LE. The continuing challenge of parastomal hernia: failure of a novel polupropylene mesh repair. Ann R Coll Surg Engl. 1998;80(3):184-7.

32. Kasperk R, Klinge U, Schumpelick V. The repair of large parastomal hernias using a midline approach and a prosthetic mesh in the sublay position. Am J Surg. 2000;179(3):186-8.

33. Kelly ME, Behrman SW. The safety and efficacy of prosthetic hernia repair in clean-contaminated and contaminated wounds. Am Surg. 2002;68(6):524-8.

34. Porcheron J, Payan B, Balique JG. Mesh repair of paracolostomal hernia by laparoscopy. Surg Endosc. 1998;12(10):1281.

35. Bickel A, Shinkarevsky E, Eitan A. Laparoscopic repair of paracolostomy hernia. J Lap Adv Surg Tech. 1999;9(4):353-5.

36. Voitk A. Simple technique for laparoscopic paracolostomy hernia repair. Dis Colon Rectum. 2000;43(10):1451-3.

37. Kozlowski PM, Wang PC, Winfield HN. Laparoscopic repair of incisional and parastomal hernias after major genitourinary or abdominal surgery. J Endourol. 2001;15(2):175-9.

38. Dunet F, Pfister C, Denis R, Pascal T, Khalil H, Peillon C. Laparoscopic management of parastomal hernia in transileal urinary diversion. J Urol. 2002;167(1):236-7.

39. LeBlanc KA, Bellanger DE. Laparoscopic repair of paraostomy hernias: early results. J Am Coll Surg. 2002;194(2):232-9.

40. Gould JC, Ellison EC. Laparoscopic parastomal hernia repair. Surg Laparosc Endosc Percutan Tech. 2003;13(1):51-4.

41. Deol ZK, Shayani V. Laparoscopic parastomal hernia repair. Arch Surg. 2003;138(2):203-5.

42. Stelzner S, Hellmich G, Ludwig K. Repair of paracolostomy hernias with a prosthetic mesh in the intraperitoneal onlay position: modified Sugarbaker technique. Dis Colon Rectum. 2004;47(2):185-91.

43. Thorlakson RH. Technique of repair of herniations associated with colonic stomas. Surg Gynecol Obstet. 1965:20:347-50.

44. de Ruiter P, Bijnen AB. Successful local repair of paracolostomy hernia with a newly developed prosthetic device. Int J Colorectal Dis. 1992;7:132-4.

45. Aldridge AJ, Simson JN. Erosion and perforation of colon by synthetic mesh in a recurrent paracolostomy hernia. Hernia. 2001;5(2):110-2.

46. Moisidis E, Curiskis JI, Brooke-Cowden GL. Improving the reinforcement of parastomal tissues with Marlex ${ }^{\circledR}$ mesh: laboratory study identifying solutions to stomal aperture distortion. Dis Colon Rectum. 2000;43(1):55-60.

47. Williams JG, Etherington R, Hayward MWJ, et al. Paracolostomy hernia: a clinical and radiological study. $\mathrm{Br}$ J Surg. 1990;77(12):1355-7.

48. Carlson MA, Ludwig KA, Condon RE. Ventral hernia and other complications of 1000 midline incisions. South Med J. $1995 ; 88: 450-3$ 